\title{
Individual tree mortality of silver birch (Betula pendula Roth) in Estonia
}

\author{
Kobra Maleki, Andres Kiviste
}

\section{Introduction}

Tree mortality is an important driver of forest stand dynamics as it determines the formation of forest structure (Pederson 1998, Van Mantgem \& Stephenson 2007). Structural properties of forests are of great importance since they are related to ecosystem functioning and productivity, in its growth and productivity (Bobiec 2002, Frolking et al. 2009).

Tree mortality occurs when tree vigor declines due to intolerance of the tree to the negative influence of stress factors, such as drought and competition. These stress factors can lead to a wide variety of
The functioning of complex forest ecosystems is intimately related to their structural properties. Tree mortality is a major driver of forest stand dynamics and therefore plays an important role in the formation of forest structure. Data from the Estonian Network of Forest Research Plots (ENFRP) was used to estimate the mortality probability of silver birch trees (Betula pendula Roth) by using logistic models. In this study several spatial and non-spatial variables were tested to determine the most important mortality explanatory factors. Additionally, thinning variables were defined and implemented into the mortality models, to examine whether thinning practices could modify the stand structure and density, then leading to a lower mortality rate. The results of this study showed that tree mortality models that included either a five-year diameter growth rate $\left(\mathrm{id}_{5}\right)$ as a measure of tree vitality, or the tree relative diameter $\left(d_{\text {rel }}\right)$ as a measure of competition, or both these two variables, were substantially better than any models not including these variables. In addition, any measures of spatial aggregation (agg) and species proportion (sp) within the zone of influence markedly improved the model predictions, though the mortality probability of trees declined where there was higher aggregation and species mixture. Our results also suggested that if thinning were conducted around the birch trees, depending on the thinning intensity, the number of neighbors is effectively reduced, and consequently the competition load within the influence zone decreases, leading to healthier growth and lower mortality rates of the shade-intolerant birch trees. We thus recommend to adopt thinning regimes in mixed forest stands to foster tree species diversity, and at the same time provide adequate growing space for birch trees within the stands. This will improve the forest structure and increase the adaptive capacity of forests, which is increasingly important under changing climatic conditions.

Keywords: Betula pendula Roth, Diameter Growth, Species Proportion, Aggregation, Competition causes of tree mortality. To achieve a better understanding of mortality, numerous attempts to categorize its causes have been reported (Vanclay 1994, Pederson 1998, Yang et al. 2003). As a simplified approach, mortality has been generally considered either as regular, due to competition or ageing, or as irregular, caused by ecological and catastrophic events, such as storm or fire (Monserud 1976). The probability of regular mortality is believed to be U-shaped, indicating relatively high mortality rates for small and large trees due to light competition and senescence, respectively (Monserud \& Sterba 1999, Lo-
Estonian University of Life Sciences, Institute of Forestry and Rural Engineering, Department of Forest Management, Kreutzwaldi 5-1B18, Tartu 51014 (Estonia)

@ Kobra Maleki (kobra.maleki@emu.ee)

Received: Apr 10, 2015 - Accepted: Dec 03, 2015

Citation: Maleki K, Kiviste A (2016). Individual tree mortality of silver birch (Betula pendula Roth) in Estonia. iForest 9: 643-651 - doi: 10.3832/ifor1672-008 [online 2016-04-04]

Communicated by: Rupert Seidl rimer et al. 2001, Fraver et al. 2008). The probability of irregular mortality is rather fluctuating, and thus quite difficult to predict, since it may be triggered by various biotic and abiotic factors, which change temporally and spatially, e.g., the attack of pests or diseases may cause a comparatively small mortality in one year, or eliminate the host species from the region (Vanclay 1994).

The ability of a tree to withstand stress factors is affected by a multitude of interacting factors such as tree size, tree viability, competition among trees and stand density (Hamilton 1986). However, diagnosing these factors as contributors to tree mortality and evaluating their relative importance can be very difficult (Das et al. 2008); especially in times of global changes it is important to broaden our understanding of tree mortality as a primary driver of changes in the composition and structure of forest communities. Maintaining a forest is essential to provide important services, such as carbon sequestration, water purification, and timber production, as well as future habitats for a large diverse number of species (Dietze \& Moorcroft 2011).

Measurements of tree size can be easily 
collected (tree diameter and tree height) or computed (tree growth and tree basal area) and to some extent they contain valuable, but not sufficient, information about the probability of tree mortality (Monserud \& Sterba 1999, Yang et al. 2003). Diameter growth rate (Buchman 1983), or as a substitute, crown size (Avila \& Burkhart 1992, Monserud \& Sterba 1999) have proven to be suitable measures of tree vitality in mortality studies.

Competition is the next well-documented contributor to tree mortality. Competition for limited resources (such as water, light and nutrients) is a fundamental ecological process, which has strongly modulated the mortality of suppressed trees (Keddy 1989, Szwagrzyk \& Szewczyk 2001). Competition among individuals can be either asymmetric or symmetric. Under asymmetric competition, larger trees are not affected by smaller trees and can therefore benefit of a greater share of resources, whereas in symmetric competition all trees have an equal share of resources, and therefore impose some competitive influence on their neighbors, regardless of their sizes (Cannell et al. 1984, Freckleton \& Watkinson 2001). Occasionally, some trees may withstand the competition pressure, but will eventually end up in a "death spiral" (Franklin et al. 1987), since trees suffering competition over long periods will weaken and eventually die due to other reasons (Wyckoff \& Clark 2000, Antos et al. 2008, Lännenpää et al. 2008).

Theoretically, inclusion of the spatial effects in modeling the competitive environment that surrounds an individual tree is expected to improve the prediction ability of mortality (Biging \& Dobbertin 1995). An increment in local density is assumed to increase the density-dependent mortality, or self-thinning, since many species are unable to endure deep shading in their dense neighborhood (He \& Duncan 2000, GómezAparicio et al. 2009). In young dense stands where trees are subjected to selfthinning, such assumption was proven to be valid (Oliver \& Larson 1996). Several studies have been conducted to define the limit to the number of trees with a given average size growing in a stand (the so called "limiting density"), depending on the forest type and the environmental conditions (Reineke 1933, Zeide 1987, Hynynen 1993, Nilson 2006, Von Gadow et al. 2015). On the other hand, when stands grow to maturity, generally the size of surviving trees and their spacing increase, and stands become less clumped. In such stands the density-dependent mortality decreases, and trees may die because of other factors, such as pathogen and insect attacks (Kenkel 1988, Franklin \& Van Pelt 2004).

Regarding the fact that any desired tree species may be absent due to self-thinning in a final regular stand, thinning during the early self-thinning years is an acceptable management tool to control stand quality and supports favorable tree species (Simard et al. 2004). Early thinning improves the tree growth by reducing the competition stress for the remaining trees (Oliver \& Larson 1996), while the thinning of suppressed trees at intermediate development stages reduces economical loss from tree deaths (Perry 1985). Thinning to different reduced densities influences the tree mortality rate, and individual trees may react differently to the same treatment. For example, small trees survive better in a less competitive neighborhood (Uriarte et al. 2004), while the mortality rate of large trees increases due to exposing their crowns to strong winds when neighboring trees are removed (Thorpe et al. 2008).

We focused our study on the mortality of silver birch trees (Betula pendula Roth), an ecologically essential broadleaf tree species (Hynynen et al. 2010) and the second most important tree species in Estonia in terms of forest cover (31.2\% and this coverage is expanding - Yearbook of Forest 2013). As a pioneer tree species (Fischer et al. 2002), silver birch grows naturally in boreal and northern temperate biomes. This species is intolerant to shade and remains vital and vigorous where it occurs as a dominant species in a relatively wide spacing, and under less favorable environmental conditions for other tree species (Hynynen et al. 2010).

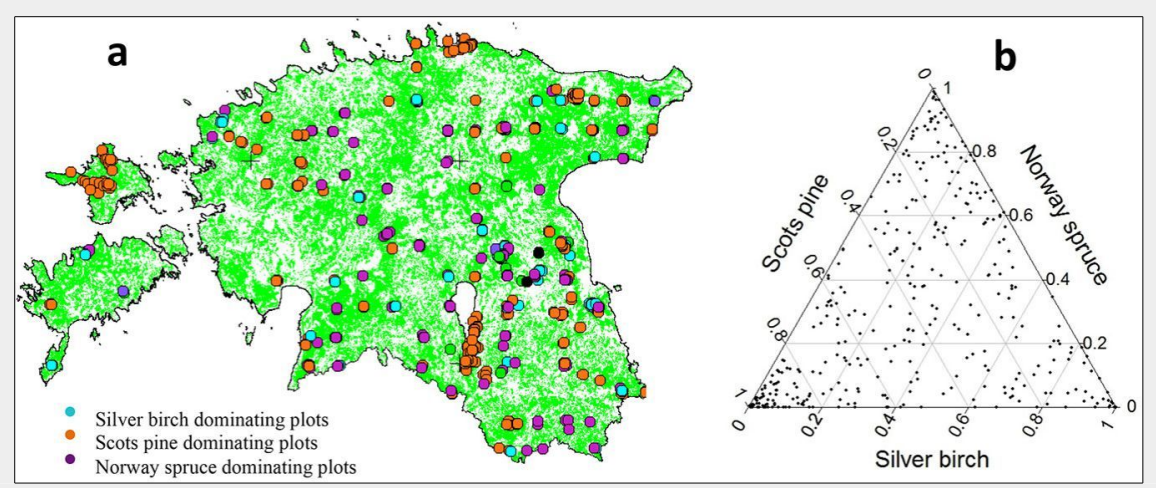

Fig. 1 - (a) The distribution of study plots throughout Estonia, and (b) the proportion of three major tree species within the study plots.
The main objectives of this study were to: (i) filter the variables that are meaningful for the mortality of silver birch trees; (ii) test these variables in an empirical model for their ability to predict mortality of silver birch trees; and (iii) examine whether thinning practices effectively minimize the rate of tree mortality in managed forests.

\section{Materials and methods}

\section{Study data}

Data from the Estonian Network of Forest Research Plots (ENFRP) was used for this study. This network, consisting of 730 permanent plots, was established during the period 1995-2004, and contains the data for all the main forest types in Estonia (Kiviste et al. 2015). The Republic of Estonia lies on the eastern shores of the Baltic Sea and along the southern shore of the Gulf of Finland $\left(57.3^{\circ}-59.5^{\circ} \mathrm{N}, 21.5^{\circ}-28.1^{\circ} \mathrm{E}\right)$. The climate varies from maritime to continental. Average temperature ranges from 16.3 to $18.1{ }^{\circ} \mathrm{C}$ in July (the warmest month) and from -3.5 to $-7.6^{\circ} \mathrm{C}$ in February (the coldest month). Mean annual precipitation is within the range $600-700 \mathrm{~mm}$, and decreases from east to west (Tarand et al. 2013).

Clear cutting is the predominant management system in Estonia; consequently overstory trees are mostly even-aged. Most stands have been managed to maintain pure stands, though near-natural situations can occur under good forest growth conditions in any stand after some decades without management. The ENFR permanent plots were circular with a radius ranging from 10 to 30 meters. Depending on the stand age and density, they were delineated so that every plot contained at least 100 trees in the overstory. Within each plot the azimuth, the distance from plot center, the diameter at breast height (d), the tree species identity, and any defects of trees were recorded. For every fifth tree, and also for dominant and rare tree species, the tree height and the height to the live crown base were also measured. The measurements were repeated at intervals of five years.

To carry out this study, we selected 422 research plots with three consecutive measurements where silver birch was present. Other plots of the ENFRP network were excluded because either the plots did not include silver birch or at least three measurements taken at five-year intervals were not available. We used the first five-year interval, i.e., the period between the first and second measurements, for the evaluation of growth and thinning rates, and the second five-year interval, i.e., the period between the second and third measurements, for the mortality study. During the first period, trees were harvested within 93 plots with different thinning intensity ranging from 0.1 to $80 \%$ of the total number of trees $(0.3-60 \%$ of the basal area). Seventyfour plots were discarded from the analysis because thinning was practiced within the 
plots in the second interval, or before the first interval. Overall, 61685 recorded tree measurements were considered in 348 selected plots. The species composition of the plots was $25.6 \%$ Scots pine (Pinus sylvestris L.), $33.9 \%$ silver birch, $26.8 \%$ Norway spruce (Picea abies L.) and $13.7 \%$ of several other species (e.g., Alnus glutinosa L., Alnus incana L. and Populus tremula L.). Fig. 1 shows the distribution of the selected study plots throughout Estonia (a) and the proportion of the three major tree species within those plots (b).

\section{Predictors of tree mortality}

Based on the concept of the influencezone (Staebler 1951) we assumed an imaginary circle in which the center is defined by a tree, and its radius is $40 \%$ of the average height of trees in the first storey on each plot (Sims et al. 2009, Maleki et al. 2015). In order to avoid biased estimations due to the interference from immediate non-measured neighboring trees outside the plot boundary, we established a boundary strip (buffer zone) inside the monitoring plot with a width equal to the radius of the influence zone. The mortality study was performed only for trees inside the reduced plot (reference trees) for which the neighbors' information was available. The distribution of plots by the number of reference trees, and the plots with an average number of neighbors within the reference trees' influence zones by the radius of the influence zone are presented in Fig. $2 a$ and Fig. 2b, respectively.

A list of selected variables studied for the contribution in tree death is provided in Tab. S1 of the Supplementary Material. As we here aimed to investigate the suitability of neighborhood spatial information to predict tree mortality, the variables were classified into spatial (where the neighboring trees' co-ordinates within the influence zones were required) and non-spatial (where the neighboring trees' co-ordinates were not used).

Non-spatial variables are simple functions of stand or tree level measurements. In Tab. S1 of the Supplementary Material the most common stand variables like density $\left(N_{\text {ha }}\right)$, basal area $\left(G, \mathrm{~m}^{2} / \mathrm{ha}\right)$, site index $\left(S I_{100}\right.$, $\mathrm{m})$ and stand age (age, year), were calculated from plot data. Variables $N_{\text {ha }}$ and $G$ can be treated as measures of stand density (Eid \& Tuhus 2001, Burgman et al. 1994), while $G$ can be considered as a measurement of symmetric competition (Bravo et al. 2001). The site index $S I_{100}$ was used to measure the site productivity, calculated as the average height of a stand at the reference age of 100 years (Nilson 1999).

For non-spatial tree level measurements the following variables were used: tree diameter at breast height $(d b h, \mathrm{~cm})$, relative tree diameter $\left(d_{\text {rel }}\right)$ calculated as the ratio of tree and stand diameters, tree fiveyear diameter growth $\left(i d_{5}, \mathrm{~cm}\right)$, tree basal area $\left(g, \mathrm{~m}^{2}\right)$, and the sum of the trees' basal areas (per plot) larger than the refer-
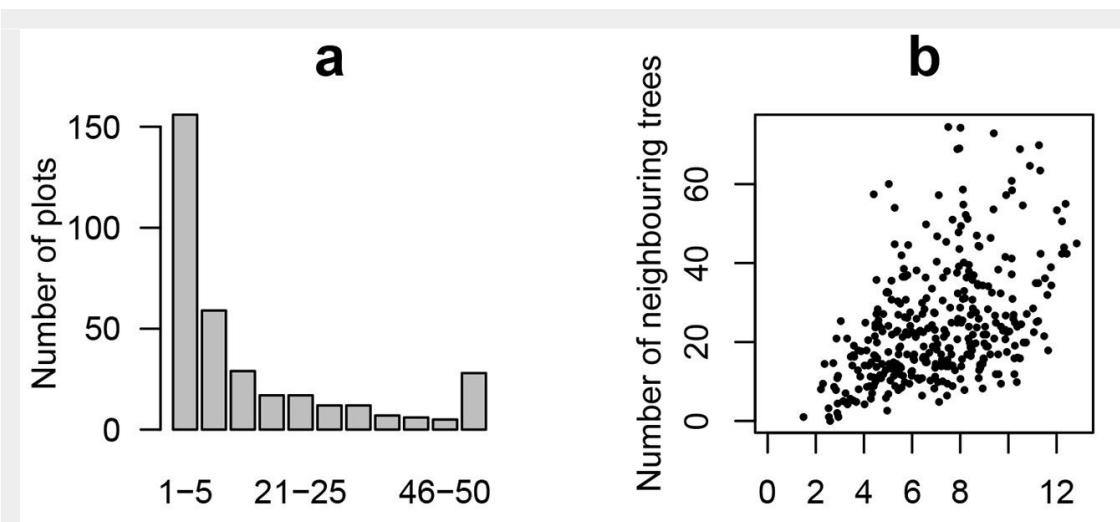

Fig. 2 - (a) Distribution of plots by number of reference trees within the studied plots; (b) relationship between the radius of the influence zone and the average number of neighbors within the reference trees' influence zones; (c) relationship between the five-year diameter growth and relative diameter in reference tree data set; (d) relationship between quadratic mean diameter and relative sparsity, where plot relative sparsity was calculated as limiting sparsity relative to stand sparsity: $L_{\lim } / L$.

ence tree ( $B A L, \mathrm{~m}^{2}$ ha-1 - Wykoff et al. 1982). The tree diameter integrates the past competitive interactions of the reference trees (Soares \& Tomé 1999), while $d_{\text {rel }}$ shows the dominance of a reference tree related to other trees in the stand. The tree diameter growth rate $\left(i d_{5}\right)$ is a measure of tree vitality often used in mortality models (Hamilton 1986, Das et al. 2007). Fig. 2c shows the relationship between the diameter growth and the relative diameter in the reference tree data set. Trees with negative diameter increment were not excluded from the data set in order to avoid bias toward positive growth, because the occurrence of undetectable overestimation of growth is unavoidable. The value of $B A L$ can be used as a measure of asymmetric competition (Monserud \& Sterba 1999, Yang et al. 2003). When considering the influence of the neighborhood, the alternative estimates of the relative diameter and the sum of the basal area of larger trees $\left(d_{\text {rel.cz }}\right.$ and $B A L_{\mathrm{cz}}$ ) were calculated only for trees within the influence zone around each reference tree.

Spatial variables in Tab. S1 of the Supplementary Material consisted of the wellknown Hegyi (1974) competition index (CI) as a measure of neighbouring trees' competition, an aggregation index (agg - Clark
\& Evans 1954) to measure clumping and the different measures of species proportion $(s p)$. Aggregation illustrates the spatial pattern of neighboring trees within the influence zone, where values $<1.0$ indicate an aggregated distribution of trees, and values $>1.0$ indicate a tendency toward a regular distribution. The species proportion defines the degree of spatial segregation of tree species in the stand. In this study the different values of $s p$ were calculated as follows: (i) the proportion of silver birch trees $\left(s p_{\mathrm{sb}}\right)$; (ii) the proportion of other species that are not silver birch $(s p)$; (iii) the proportion of Norway spruce trees $\left(s p_{\text {ns }}\right)$; and (iv) the proportion of Scots pine and other deciduous trees $\left(s p_{\mathrm{T}}\right)$, for all neighboring trees within the influence zone.

An important issue in stand development is the self-thinning, when an increased density-dependent mortality rate is expected due to high competition among individuals. Traditionally, the allometric relationship between stand density $\left(N_{\text {ha }}\right)$ and diameter $(D)$ has been applied for approximating the self-thinning line (Burkhart \& Tomé 2012). However, Nilson $(2005,2006)$ showed the advantage of using stand sparsity $(L, \mathrm{~m})$ by a transformation of the stand density $\left(N_{\mathrm{ha}}-\right.$ eqn. 1). 


$$
L=\frac{100}{\sqrt{\left(N_{h a}\right)}}
$$

On the basis of normal growth and yield tables used in Estonia (i.e., assuming that they describe the highest possible stand density), sparsity of silver birch stands in a self-thinning situation were calculated as follows (Vabariigi Valitsuse 2013 - eqn. 2).

$$
L_{\text {lim }}=\left(117+14.15 \cdot \frac{D^{2}}{H}\right) / 134
$$

where $D$ and $H$ are stand quadratic mean diameter $(\mathrm{cm})$ and mean height $(\mathrm{m})$, respectively. Fig. $2 \mathrm{~d}$ presents the relationship between mean square diameter and relative density $\left(L_{\text {lim }} / L\right)$ where dots with relative sparsity greater than 1.0 (69 studied plots including $17 \%$ of reference trees) crossed the self-thinning line.

Finally the thinning variables $I_{\text {thin }}$ and $C I_{\text {red }}$ were quantified, where $I_{\text {thin }}$ is the non-spatial measure of the thinning intensity within the plots, and $C I_{\text {red }}$ is the spatial measure of the reduced load of competition within the zone of influence, because of the removal of competitors during any thinning practices.

\section{Model fitting and statistical analyses}

Mortality is a discrete event that can only take two values (alive or dead), hence logistic functions are widely applied to model probability of tree mortality (Monserud 1976, Yao et al. 2001, Bravo-Oviedo et al. 2006). Since data from many plots were used and the number of reference trees were not equal for studied plots, we devised the mortality probability in a generalized linear mixed effects logistic regression for binary mortality data (eqn. 3). The predictors were combinations of different contributors to mortality (see Tab. S1 in the Supplementary Material) and the plot character was considered as a random effect that estimated the variability in different studied plots. The dependent variable was tree mortality during the second interval (last five-year period). The value of mortality was set equal to 1.0 when a tree was still alive at the time of the third measurement; otherwise the value was set to zero. Given $p$ as the probability of tree survival, 1$p$ is the probability of tree mortality (eqn. 3):

$$
\operatorname{logit}(p)=\ln \left(\frac{p}{1-p}\right)=\alpha+\beta X+\gamma Z+\varepsilon
$$

Assuming that $v$ is the number of predictors, $N$ is the number of observations, and $n$ is the number of plots, then $\alpha$ is the model intercept, $X$ is a $N \cdot v$ matrix of the $v$ predictor variables, $\beta$ is a $v$ column vector of the fixed effects model coefficients, $Z$ is the $N \cdot n$ design matrix for the random effect (the random complement to the fixed $X), \gamma$ is a vector of the random effect (the random complement to the fixed $\beta$ ) and $\varepsilon$ is a $N$ column vector of the residuals for that part of $p$ that is not explained by the model $X \beta+Z \gamma$.
Since the coefficient of determination is not appropriate when discrete variables are modeled (Bravo-Oviedo et al. 2006), the goodness-of-fit of the models was assessed using a log-likelihood statistic (loglik), Akaike Information Criteria (AIC), and Akaike weights $\left(\mathrm{AIC}_{\mathrm{w}}\right)$. The probability that the model was the best with the lowest expected information loss was determined by the smallest value of AIC and the biggest $\mathrm{AlC}_{w}$ (Wagenmakers \& Farrell 2004). $\triangle \mathrm{AIC}$ indicates the differences in AIC values between a given model and the model with the lowest AIC value. According to Burnham \& Anderson (2002), we assumed that the models with $\triangle A I C<2.0$ had a "substantial empirical support" and that these models were almost equal, whereas the models with $\triangle \mathrm{AIC}>4.0$ were considerably different. The accuracy of the models in correctly classifying the trees in dead/alive groups was also tested by the area under the receiver operating characteristic (ROC) curve (Bravo-Oviedo et al. 2006). The area under a ROC curve (AUC) quantifies the accuracy of the model, where values $>0.7$ indicate good accuracy (Fawcett 2006). Also, a classification of alive and dead trees for each model was performed using the ideal cut-point, where the sensitivity (true mortality rate) and specificity (true survival rate) curves crossed (Hosmer \& Lemeshow 2000). The val.prob function of the rms package in the $R$ statistical software ( $R$ Development Core Team 2014) was used to assess the accuracy of the models, and to validate the predicted probabilities of the logistic fits against the observed mortality.

Models were developed and selected as follows. Initially, pairwise models were calculated between mortality and each variable presented in Tab. S1 (Supplementary Material). The importance of each variable in the pairwise fits was evaluated using the analysis of variances (ANOVA) and the 10 most effective variables were selected based on their AIC values. The significance of thinning variables, $I_{\text {thin }}$ and $C I_{\text {red }}$, on mortality probability of silver birch trees was also tested. About 400 models were fitted with all possible combinations of these selected variables with the restriction that no model could simultaneously include variables representing a similar factor (e.g., one model could only have either $C I$ or $B A L$ as a measure of competition). Models were then compared using AIC values, and the best models, as well as the models with an $\mathrm{AIC}_{\mathrm{w}}$ value greater than zero, were selected.

Finally, the contribution of thinning to the

Tab. 1 - Mortality rate of silver birch trees depending on silver birch proportion.

\begin{tabular}{lcccc}
\hline $\begin{array}{l}\text { Proportion of birch } \\
\text { in influence zone (\%) }\end{array}$ & $\begin{array}{c}\text { Number of } \\
\text { reference trees }\end{array}$ & $\begin{array}{c}\text { Number } \\
\text { of plots }\end{array}$ & $\begin{array}{c}\text { Mortality to } \\
\text { survival rate }\end{array}$ & $\begin{array}{c}\text { Mortality } \\
\text { rate (\%) }\end{array}$ \\
\hline $81-100$ & 864 & 39 & 0.20 & 16.67 \\
$61-80$ & 1606 & 88 & 0.13 & 11.27 \\
$41-60$ & 1526 & 138 & 0.08 & 7.55 \\
$21-40$ & 1274 & 173 & 0.08 & 7.53 \\
$0-20$ & 739 & 246 & 0.06 & 6.09 \\
\hline
\end{tabular}

mortality of individual trees was assessed. To this purpose, variables $I_{\text {thin }}$ and $C I_{\text {red }}$ were separately added to the selected model as new predictors, and the changes to the quality measure of the full statistical model were investigated. For all models, the gimer function from the Imes package in the R statistical software was applied. Furthermore, for each combination of variables the variance inflation factor (VIF) was determined to ensure that the models were not strongly biased by multicollinearity.

\section{Results}

Over the 348 selected research plots the five-year mortality rate of silver birch trees was $9.67 \%$, i.e., out of 6009 silver birch reference trees 581 died. The mortality rate in pure stands was higher than in mixed stands (Tab. 1). There was a stronger survival probability for a silver birch tree when growing in a neighborhood that consisted of species other than birch, as the mortality rate decreased from $16.67 \%$ in a pure silver birch stand to $6.09 \%$ for single silver birch trees surrounded by other species, mainly Norway spruce and Scots pine.

The results from the pairwise analyses indicated that tree growth $\left(i d_{5}\right)$, tree size $(d b h)$, as well as competition $\left(d_{\text {rel.cz }}, C I\right.$ and $B A L_{\mathrm{cz}}$ ), structure (agg and $s p$ ), and stand size $(G)$, were the most important predictors of individual tree mortality (Fig. 3). The mortality probability of individual trees was negatively correlated with $d b h, i d_{5}, s p$, and agg, but the correlation was positive for competition and stand size. The other studied variables (see Tab. S1 in the Supplementary Material) showed non-significant effects in the current mortality study. In an attempt to take the site quality into consideration, the site index at reference age of 50, and the site type as a nominal variable, as alternatives to $S I_{100}$, were also tested, but they did not provide any improvement to the model performance.

The highest ranked logistic models with different combinations of variables are presented in Tab. 2 in two categories: some models included only non-spatial mortality predictors, and both spatial and non-spatial variables were fitted into other models. The models consisting of spatial variables far exceeded those with non-spatial measurements in terms of AIC and $\mathrm{AIC}_{\mathrm{w}}$. The VIF values for all combinations were less than 3.0, indicating a low multicollinearity. Additionally, we tested different transformations of $d b h, d_{\text {rel }}$ and $i d_{5}$, and found them 
Fig. 3 - Predicted mortality probability of the most important predictors of the tree mortality (solid lines) with $95 \%$ confidence (dashed lines) in pairwise relationship between mortality and predictor variables. b1 (black lines) and b2 (red lines) refer to variables $d_{\text {rel }}$ and $d_{\text {rel.cz, }}$, while e1

(black lines) and ez (red lines) refer to the variables $B A L$ and $B A L_{c z}$, respectively.

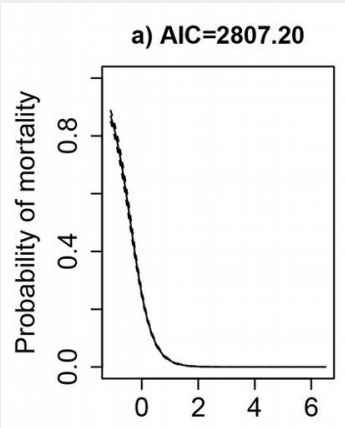

5 -year dbh growth $(\mathrm{cm})$

e1) AIC $=3052.09$ e2) $\mathrm{AIC}=3222.73$

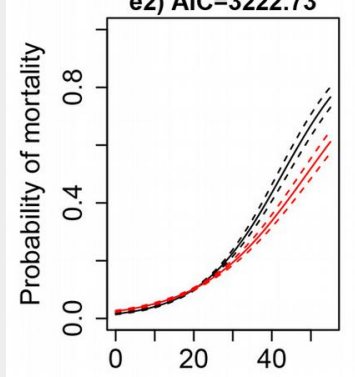

Nonspatial competition (BAL)

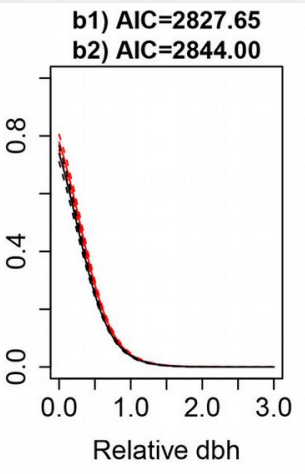

f) $A I C=3141.22$

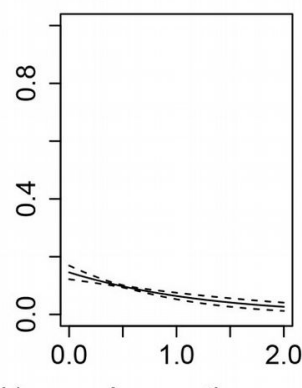

Aggregation c) $\mathrm{AIC}=2969.21$

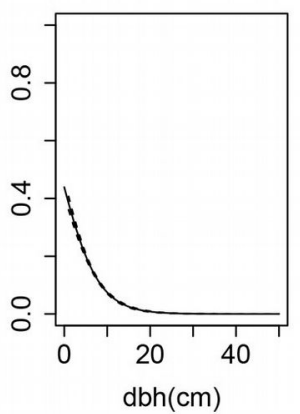

g) $\mathrm{AIC}=3536.17$

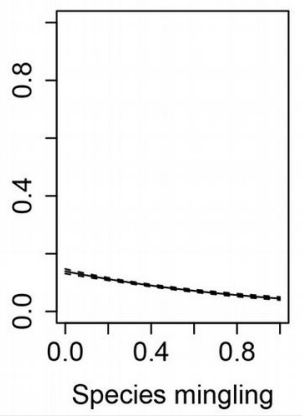

d) $\mathrm{AIC}=3037.08$

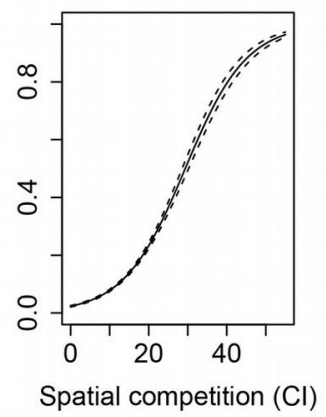

h) $\mathrm{AIC}=3542.35$

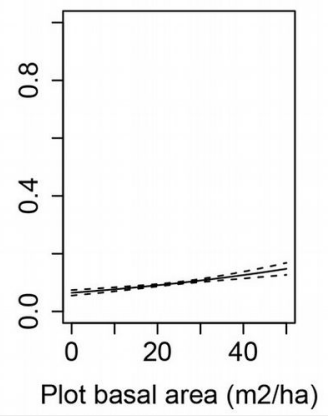

Tab. 2 - Mortality probability analyses of silver birch using different spatial and non-spatial variables. id ${ }_{5}$ is the five-year diameter growth of reference trees $(\mathrm{cm})$; dbh is the diameter of reference tree at breast height $(\mathrm{cm}) ; d_{\text {rel }}$ and $d_{\text {rel.cz }}$ are the relative dbh of reference trees for each plot and zone of influence, respectively; $G$ is the total basal area of trees within the plot $\left(\mathrm{m}^{2} \mathrm{ha} \mathrm{a}^{-1}\right) ; \mathrm{BAL}$ and $B A L_{c z}$ are the sum of basal area of trees larger than the reference tree within the plot and the influence zone, respectively $\left(\mathrm{m}^{2}{ }^{2} \mathrm{ha}\right)$; $\mathrm{Cl}$ is the Hegyi's competition measure of neighbouring trees inside the zone of influence; agg is the aggregation measure of trees inside the zone of influence and sp is the proportion of other species than silver birch within the influence zone. AIC, $\triangle \mathrm{AIC}$, AUC and loglik are the statistical measures of the models. TPR and TNR are the sensitivity and specificity of the models, respectively.

\begin{tabular}{lcccccc}
\hline Variables & AIC & $\Delta$ AIC & AUC & TPR & TNR & loglik \\
\hline$I d_{5}, d_{\text {rel }}, s p, a g g$ & 2583.64 & 0.00 & 0.819 & 0.828 & 0.856 & -1285.8 \\
$I d_{5}, d_{\text {rel }}, s p$ & 2590.37 & 6.73 & 0.819 & 0.833 & 0.853 & -1290.18 \\
$I d_{5}, d_{\text {rel }}, a g g$ & 2593.54 & 9.90 & 0.820 & 0.812 & 0.866 & -1291.77 \\
$I d_{5}, d_{\text {rel.cz }}, s p$ & 2593.82 & 10.18 & 0.818 & 0.816 & 0.861 & -1291.91 \\
$I d_{5}, d_{\text {rel.cz }}, s p, a g g$ & 2596.56 & 12.92 & 0.818 & 0.818 & 0.862 & -1294.78 \\
$I d_{5}, d_{\text {rel }}, d b h$ & 2600.86 & 17.22 & 0.820 & 0.816 & 0.862 & -1295.43 \\
$I d_{5}, d_{\text {rel.cz }}, a g g$ & 2601.25 & 17.61 & 0.817 & 0.809 & 0.864 & -1295.63 \\
$I d_{5}, d_{\text {rel }}$ & 2603.11 & 19.47 & 0.820 & 0.833 & 0.854 & -1297.55 \\
$I d_{5}, d_{\text {rel }}, G$ & 2605.08 & 21.44 & 0.820 & 0.831 & 0.854 & -1297.54 \\
$I d_{5}, d_{\text {rel.cz }}, d b h$ & 2605.17 & 21.53 & 0.818 & 0.831 & 0.851 & -1297.58 \\
$I d_{5}, d_{\text {rel.cz }}, G$ & 2617.09 & 33.45 & 0.818 & 0.809 & 0.860 & -1303.55 \\
$I d_{5}, d b h, C l$ & 2619.02 & 35.38 & 0.818 & 0.833 & 0.855 & -1304.51 \\
$i d_{5}, d b h, B A L$ & 2619.27 & 35.63 & 0.818 & 0.821 & 0.858 & -1304.63 \\
$i d_{5}, d b h, a g g$ & 2625.64 & 42.00 & 0.818 & 0.833 & 0.852 & -1307.82 \\
$i d_{5}, d b h, B A L_{c z}$ & 2629.66 & 46.02 & 0.817 & 0.819 & 0.859 & -1309.83 \\
$i d_{5}, d b h, G$ & 2633.34 & 49.70 & 0.818 & 0.824 & 0.859 & -1312.67 \\
\hline
\end{tabular}

inferior to the untransformed variables (data not shown).

Fig. 4 shows a comparison of the predicted mortality probability of reference trees with their observed mortality probability for the best logistic model. The predictive performance of the best model was good; however, a closer analysis of the estimated mortality probability revealed an evidence of negligible overestimation of the mortality prospects of very small silver birch trees $\left(d_{\text {rel }}<0.2\right)$ with low survival probability, and also a slight underestimation of the mortality probability of the small proportion of large silver birch trees $(d b h>40$ $\mathrm{cm}$, see sensitivity and specificity values in

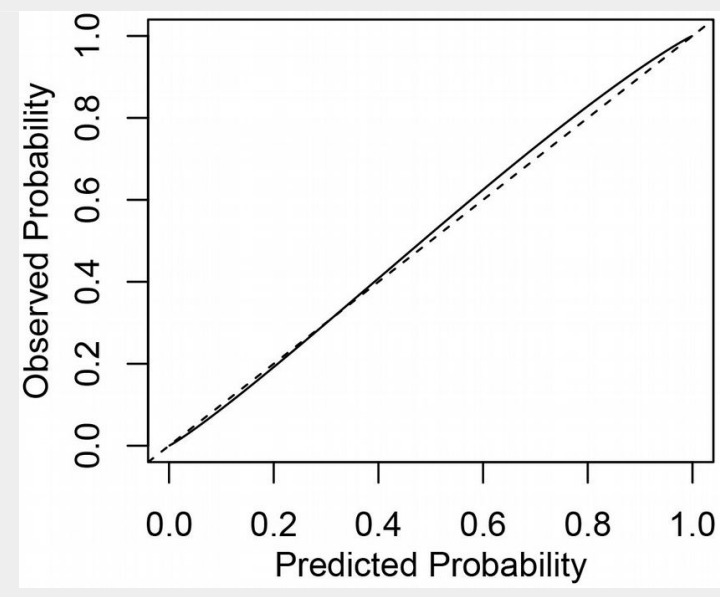

Fig. 4 - The predicted mortality probabilities of the best logistic model against observed mortality. The dashed line represents the ideal probability estimation and the solid line shows how the model fits observed mortality probabilities. 
Tab. 3 - The best combinations of variables predicting silver birch mortality when thinning is included as predictor in the model used. $\left(i d_{5}\right)$ : five-year diameter growth of tree $(\mathrm{cm}) ;\left(d_{\text {rel }}\right)$ : relative $d b h$ of reference trees for each plot; $\left(C i_{\text {red }}\right)$ : Hegyi's competition measure of thinned trees inside the zone of influence; $\left(I_{\text {thin }}\right)$ : thinning intensity of the plot; $(a g g)$ : aggregation of trees inside the zone of influence; (sp): proportion of other species than silver birch within the influence zone. $\triangle \mathrm{AIC}$ and $\mathrm{AIC}_{\mathrm{w}}$ are the statistical measures of models. AUC, TPR and FPR are area under curve, true positive rate and false positive rate of dead trees, respectively. Coeff ${ }_{i}$ are coefficients of the models. TPR and TNR are the sensitivity and specificity of the models, respectively.

\begin{tabular}{|c|c|c|c|c|c|c|c|c|c|c|c|}
\hline Variables & $\triangle \mathrm{AIC}$ & $\mathrm{AIC}_{\mathrm{w}}$ & AUC & TPR & TNR & Intercept & Coeff $_{1}$ & Coeff $_{2}$ & Coeff $_{3}$ & Coeff $_{4}$ & Coeff $_{5}$ \\
\hline$i d_{5}, d_{\text {rel }}, s p, a g g$, & 0.00 & 0.655 & 0.819 & 0.833 & 0.856 & 2.324 & -1.977 & -3.263 & -1.1053 & -1.008 & -0.195 \\
\hline$i d_{5}, d_{\text {rel }}, s p, a g g$ & 2.49 & 0.189 & 0.819 & 0.828 & 0.856 & 2.327 & -1.985 & -3.232 & -1.103 & -1.054 & - \\
\hline$i d_{5}, d_{\mathrm{rel}}, s p, a g g, I_{\text {thin }}$ & 2.86 & 0.157 & 0.819 & 0.811 & 0.863 & 2.303 & -1.981 & -3.262 & -1.098 & -0.993 & -1.273 \\
\hline
\end{tabular}

Tab. 3). More detailed examinations also revealed that some models had overestimated the likelihood of smaller tree survival. Moreover, a tendency to underestimate the survival likelihood of silver birch trees with small relative diameters in the unthinned plots was detected.

As shown in Tab. 3, the inclusion of the non-spatial variable $I_{\text {thin }}$ in the best model did not seem to improve its performance. However, a significant improvement was observed when the spatial thinning variable $C i_{\text {red }}$ was included. Thus, thinning practices in silver birch stands demonstrated that there was a negative influence on the probability of tree mortality (see Coeff $_{5}$ in Tab. 3) by reducing the competition. Therefore, an excessive decrease in the number of trees due to high thinning intensity, and consequently a reduction in competition, could also decrease the tree mortality rate (from $10.1 \%$ in unthinned plots to $6.6 \%$ in thinned plots). Additionally, the accuracy estimated by AUC was excellent (AUC $>0.8)$ for all the models in Tab. 3 (Hosmer \& Lemeshow 2000). These high values indicated that many of the dead trees (true positives) were correctly classified.

\section{Discussion}

\section{Drivers of silver birch mortality}

In this study, the silver birch trees with an increasing diameter growth rate clearly indicated an increment in survival. Recent radial growth has been frequently used as an indicator of tree health and vigor (Kobe 1996, Yao et al. 2001). Accordingly, it is biologically meaningful to assume an improved survival for trees showing higher growth rates, while the opposite is expected for trees showing feeble growth. As a consequence, the probability of any tree to survive can be inferred from its diameter increment (Waring 1987). On the other hand, since radial growth rate varies systematically by tree size after an initial increase, the radial growth rate often decreases as the tree diameter increases, and therefore, diameter growth rate tends to overestimate the mortality probability of bigger trees as compared with smaller trees. It has been proposed that basal area growth rate is a better measure of tree survival than diameter growth rate (Pederson 1998, Ireland et al. 2014). Basal area growth rate represents the tree mass growth more closely, as it increases with tree size (Clark \& Clark 1999, Di Filippo et al. 2012). Similar to Das \& Stephenson (2015), our results did not indicate any better prediction of tree mortality when basal area growth is included in the model (data not shown). On the other hand, we observed a systematic overestimation of the mortality probability of small birch trees.

While the mortality of small birch trees in young and dense stands increased due to self-thinning (Barnes et al. 1998), in older stands the high mortality of small trees can be attributed to the suppression by dominating trees- where the non-spatial explanatory variable $d_{\text {rel }}$ appeared superior to capture this trend. By some means, the hierarchical position of trees within the stand is measured by $d_{\text {rel }}$ and indirectly indicates their competitive status (Burkhart \& Tomé 2012). We found that competition is a significant mortality driver, in accordance with the extensive literature corroborating such relationships in the Estonian forests (Laarmann et al. 2009, Sims et al. 2009) and in other forests (Monserud et al. 2004, Temesgen \& Mitchell 2005, Bravo-Oviedo et al. 2006, Das et al. 2011). Moreover, the reversed J-shaped (L-shaped) size-dependent mortality pattern of our studied trees (Fig. 3) can be explained by the insufficient number of large trees, and the high mortality rates of young trees within the stands where the competition for resources is high (Coomes \& Allen 2007, Olano et al. 2009, Dietze \& Moorcroft 2011).

The competition-induced mortality is presumed to decline as local tree density decreases, and the overall plot density showed to be related to the strength of competitive effects (Gonzalez et al. 2004, Temesgen \& Mitchell 2005). The variable $d_{\text {rel }}$ could have served as a simple index of competition, but it did not take the variation of stand density into account. Therefore, equipping the model with spatial measures that represented the neighborhood properties of reference trees did appear unavoidable. Surprisingly, contrary to our assumption, adding the new calculations of $B A L\left(B A L_{\mathrm{cz}}\right)$ and $d_{\text {rel }}\left(d_{\text {rel.cz }}\right)$ only for immediate neighbors inside the influence zone diminished the predictive power of the model. This can be explained by the expected increasing uniformity in tree spacing with tree age or size, due to mortality from competition (Jose et al. 1991, Moeur
1997, Druckenbrod et al. 2005). Therefore, for some small birch trees in old and regular stands, and also for some big birch trees in young and clumped stands, the real values of competition and relative diameter may not be measured by considering the influence zone (here as a ratio of stand height). Finally, the inclusion into the model of the aggregation measure (agg) could take into consideration the horizontal spatial arrangement of tree positions inside the influence zone. The aggregation index has been successfully used to assess the regularity of tree positions (Pommerening 2002, Aguirre et al. 2003, Brumelis et al. 2005). In our study, agg efficiently proved the negative influence of clumping $(a g g<1)$ on the survival prospects of birch trees (see Tab. 3, negative coefficients for agg in the mortality models).

Several studies reported that the competition and growth of silver birch trees, and consequently their survival prospects, are strongly related to the identity of neighboring species (Kaitaniemi \& Lintunen 2010, Jõgiste 2010, Hynynen et al. 2011). Their findings are consistent with our results, in that including $s p$ to the best nonspatial mortality model definitely improved its fit. The mortality likelihood of a birch tree was negatively related to the species mixture of its immediate neighbors (decreasing from pure stands to mixed stands - Tab. 2, Tab. 3). According to the JanzenConnell's type effect, this may be caused either by the increased risk of attack by species-specific herbivores or diseases, when a silver birch tree grows in close proximity to many other con-specifics (Janzen 1970, Connell 1971). Also, the inter-specific competition among hetero-specific individuals (mainly Norway spruce and Scots pine) appeared lower than the competition among conspecific individuals (i.e., neighboring silver birch trees). Due to a similar demand for light and resources, the competition among neighboring silver birch individuals increases, and therefore the competition-induced mortality is relatively high. Norway spruce and birch trees have similar site requirements, but when occurring together the formers seem more shade-tolerant than the light-demanding birches, and also show different temporal growth patterns (Tahvanainen \& Forss 2008, Hynynen et al. 2011). Moreover, birch trees easily overwhelm and suppress the 
shade-intolerant Scots pine trees due to their vigorous early growth (Hynynen et al. 2011); however, their co-occurrence is relatively infrequent due to different site requirements.

\section{The effect of thinning on silver birch mortality}

Thinning to different residual densities produces varying effects on tree mortality, depending on the tree species with different characteristics and site conditions ( $\mathrm{He}$ \& Duncan 2000, Canham et al. 2001, Uriarte et al. 2004). Some studies have found a higher mortality risk during the first years after thinning, either due to mechanical damage to the remaining trees (Nyland 1994, Caspersen 2006), or by shifting the population towards smaller trees more prone to environmental stresses, or even to windfall for larger residual trees on the margin of cutting areas (Jönsson et al. 2007, Fortin et al. 2008). In contrast, some studies have reported that thinning operations may rescue trees from density-dependent mortality (Powers et al. 2010). In our case, the mortality of silver birch trees was affected negatively by thinning operations within the plots (up to $3.5 \%$ decline in mortality rate of birch trees in thinned stands). The slight improvement of performance of the mortality model obtained by including $C I_{\text {red }}$ indicated that the competition imposed by neighboring trees, which were cut during the thinning operation, partially limited the survival of birch trees. As explained before, density-dependent mortality or self-thinning (Drew \& Flewelling 1977) occurs when the stand sparsity is smaller than the limiting sparsity. Thinning operations have successfully increased the stand sparsity, and released the shade-intolerant birch trees that showed a vigorous growth within a less competitive environment.

\section{Data limitation}

The areas included in the Estonian Network of Forest Research Plots (ENFRP) were mostly located in managed forests, i.e., only a few old dense stands were measured in this study. The record of the age of individual trees was not available and the age was only determined for tree cohorts. Since regular mortality of a tree could be dependent on its age (Monserud 1976), including the exact age of trees may have improved the model's strength. However, determining the age of individual trees in practical forest management is too laborious. Another factor of uncertainty is the inclusion of small plots when applying spatial variables. As mentioned above, a buffer zone inside the plot (near the plot boundary) was applied to avoid the biased estimations due to edge effects. Consequently, a relatively large number of trees were excluded from mortality analyses, and this loss was more relevant for small plots. However, for the simulation of the neighborhood, a border method (Ripley
1981) was used as a means to eliminate this effect, as described by Lilleleht et al. (2014). This method is simple to implement in comparison with other methods, and guarantees the removal of all edge effects (Kint et al. 2004).

Additionally, one might expect that building the mortality model to include soil descriptors and climate variables will also improve its performances. In this study, mortality was assessed over periods of five years as the exact year of tree death was unknown. Thus, it was difficult to connect extreme events, such as very cold temperatures or hot summers, which can usually cause high tree mortality. Regarding the costly assessment of annual tree mortality and soil analysis around individual trees for large data sets, a dendrochronological analysis seems to be a more effective method for climate studies (Linares et al. 2009). Further studies are needed to investigate the efficiency of the mentioned variables and other possible mortality predictors in defining the live/death status of individuals.

\section{Conclusions}

Natural mortality of individual trees is a stochastic and irregular phenomenon for which we attempted to find the most relevant explanatory variables. Although a number of known and unknown factors affecting tree mortality makes its modeling complicated, the fitted models used in this study did produce results that satisfactorily explained mortality of Estonian silver birch trees. Five-year diameter growth, relative diameter, species proportion, and aggregation were the most appropriate explanatory variables in our mortality models. In order to maintain high survival probabilities, forest management plans and practices should pay a special attention to growth performances of trees, species compositions, tree density and forest stand structure. Furthermore, the reduction of stand density would provide more growing space for light-demanding birch trees, as demonstrated by the reduced mortality predicted by our model when thinning was included as predictor. However, root and stem damage caused by heavy machinery used for thinning operations, and the higher wind exposure of trees after thinning should also be considered. Finally, based on our results, silver birch trees should preferably be managed in mixed stands where they occur along with other tree species, and attempts should be made to minimize the clumping $(a g g>1)$ within their neighborhoods.

\section{Acknowledgements}

Measurement of the Estonian Network of Forest Research Plots has been supported by Estonian Environmental Investment Center. This study was also supported by the Estonian Research Council (ETF8890, IUT21-04).

\section{References}

Aguirre O, Hui G, Von Gadow K, Jimenez J (2003). An analysis of spatial structure using neighbourhood based variables. Forest Ecology and Management 183: 137-145. - doi: 10.1016/ S0378-1127 (03)00102-6

Antos J, Parish R, Nigh G (2008). Growth patterns prior to mortality of mature Abies lasiocarpa in old-growth subalpine forests of southern British Columbia. Forest Ecology and Management 255: 1568-1574. - doi: 10.1016/j.foreco. 2007.11.022

Avila OB, Burkhart HE (1992). Modelling survival of loblolly pine trees in thinned and unthinned plantations. Canadian Journal of Forest Research 22: 1878-1882. - doi: 10.1139/x92-245

Barnes BV, Zak DR, Denton SR, Spurr SH (1998). Forest ecology ( $4^{\text {th }}$ edn). John Wiley \& Sons, New York, USA, pp. 774.

Biging G, Dobbertin M (1995). Evaluation of competition indices in individual tree growth models. Forest Science 41: 360-377.

Bobiec A (2002). Living stands and dead wood in the Bialowieza forest: suggestions for restoration management. Forest Ecology and Management 165: 125-140. - doi: 10.1016/S0378-1127(01) 00655-7

Bravo F, Hann DW, Maguire DA (2001). Impact of competitor species composition on predicting diameter growth and survival rates of Douglasfir trees in south western Oregon. Canadian Journal of Forest Research 31: 2237-2247. - doi: 10.1139/x01-164

Bravo-Oviedo A, Sterba H, Del Rio M, Bravo F (2006). Competition-induced mortality for Mediterranean Pinus pinaster Ait. and P. sylvestris L. Forest Ecology and Management 222: 88-98. - doi: 10.1016/j.foreco.2005.10.016

Brumelis G, Elferts D, Liepina L, Luce I, Tabors G, Tjarve D (2005). Age and spatial structure of natural Pinus sylvestris stands in Latvia. Scandinavian Journal of Forest Research 20: 471-480. doi: $10.1080 / 02827580500339526$

Buchman RG (1983). Survival predictions for major lake states tree species. Research Paper NC-233, North Central Forest Experimental Station, USDA Forest Service. St. Paul, MN, USA, pp. 7.

Burgman MA, Incoll W, Ades PK, Ferguson I, Fletcher TD, Wohlers A (1994). Mortality models for mountain and alpine ash. Forest Ecology and Management 67: 319-327. - doi: 10.1016/037 8-1127(94)90026-4

Burkhart HE, Tomé M (2012). Modelling forest trees and stands. Springer, Dordrecht, The Netherlands, pp. 458.

Burnham K, Anderson D (2002). Model selection and multi-model inference: a practical information-theoretic approach. Springer Verlag, New York, USA, pp. 488.

Canham CD, Papaik MJ, Latty EF (2001). Interspecific variation in susceptibility to windthrow as a function of tree size and storm severity for northern temperate tree species. Canadian Journal of Forest Research 31: 1-10. - doi: 10.1139 |xoo-124

Cannell MGR, Rothery P, Ford ED (1984). Competition within stands of Picea itchensis and Pinus contorta. Annals of Botany 53: 349-362.

Caspersen JP (2006). Elevated mortality of residual trees following single-tree felling in north- 
ern hardwood forests. Canadian Journal of Forest Research 36: 1255-1265. - doi: 10.1139/xo6-0 34

Clark PJ, Evans FC (1954). Distance to nearest neighbour as a measure of spatial relationships in populations. Ecology 35: 445-453. - doi: 10.23 $07 / 1931034$

Clark DA, Clark DB (1999). Assessing the growth of tropical rain forest trees: issues for forest modeling and management. Ecological Applications 9: 981-997. - doi: 10.1890/1051-0761(1999) 009[0981:ATGOTR]2.0.CO;2

Connell JH (1971). On the role of natural enemies in preventing competitive exclusion in some marine animals and in rain forest trees. In: "Dynamics of Population" (Den Boer PJ, Gradwell GR eds). Centre for Agricultural Publishing and Documentation, Wageningen, The Netherlands, pp. 298-312.

Coomes DA, Allen RB (2007). Mortality and treesize distributions in natural mixed-age forests. Journal of Ecology 95: 27-40. - doi: 10.1111/j.13652745.2006.01179.x

Das A, Battles J, Stephenson NL, Van Mantgem PJ (2007). The relationship between tree growth patterns and likelihood of mortality: a study of two tree species in the Sierra Nevada. Canadian Journal of Forest Research 37: 580597. - doi: 10.1139/Xo6-262

Das A, Battles J, Van Mantgem PJ, Stephenson $\mathrm{NL}$ (2008). Spatial elements of mortality risk in old-growth forests. Ecology 89: 1744-1756. - doi: 10.1890/07-0524.1

Das A, Battles J, Stephenson NL, Van Mantgem PJ (2011). The contribution of competition to tree mortality in old-growth coniferous forests. Forest Ecology and Management 261: 1203-1213. - doi: 10.1016/j.foreco.2010.12.035

Das A, Stephenson NL (2015). Improving estimates of tree mortality probability using potential growth rate. Canadian Journal of Forest Research 45: 920-928. - doi: 10.1139/cjfr-2014-0368 Dietze MC, Moorcroft PR (2011). Tree mortality in the eastern and central United States: patterns and drivers. Global Change Biology 17: 33123326. - doi: 10.1111/j.1365-2486.2011.02477.x

Di Filippo A, Biondi F, Maugeri M, Schirone B, Piovesan $G$ (2012). Bioclimate and growth history affect beech lifespan in the Italian Alps and Apennines. Global Change Biology 18: 960972. - doi: 10.1111/j.1365-2486.2011.02617.x

Drew TJ, Flewelling JW (1977). Some recent Japanese theories of yield density relationships and their application to Monterey pine plantations. Forest Science 23: 517-534.

Druckenbrod DL, Shugart HH, Davies I (2005). Spatial pattern and process in forest stands within the Virginia piedmont. Journal of Vegetation Science 16: 37-48. - doi: 10.1111/j.1654-1103. 2005.tbo2336.x

Eid T, Tuhus E (2001). Models for individual tree mortality in Norway. Forest Ecology and Management 154: 69-84. - doi: 10.1016/S0378-1127 (00)00634-4

Fawcett T (2006). An introduction to ROC analysis. Pattern Recognition Letters 27: 861-874. doi: 10.1016/j.patrec.2005.10.010

Fischer A, Lindner M, Abs C, Lasch P (2002). Vegetation dynamics in central European forest ecosystems (near-natural as well as managed) after storm events. Folia Geobotanica 37: 17-32. doi: $10.1007 / B F 02803188$

Fortin M, Bédard S, DeBlois J, Meunier S (2008). Predicting individual tree mortality in northern hardwood stands under uneven-aged management in southern Québec, Canada. Annals of Forest Science 65: 1-11. - doi: 10.1051/forest:2007 088

Franklin J, Shugart H, Harmon M (1987). Tree death as an ecological process. BioScience 37 : 550-556. - doi: 10.2307/1310665

Franklin JF, Van Pelt R (2004). Spatial aspects of structural complexity in old-growth forests. Journal of Forestry 102: 22-28.

Fraver S, Jonsson BG, Jönsson M, Esseen PA (2008). Demographics and disturbance history of a boreal old-growth Picea abies forest. Journal of Vegetation Science 19: 789-798. - doi: 10.3170/2008-8-18449

Freckleton RP, Watkinson AR (2001). Asymmetric competition between plant species. Functional Ecology 15: 615-623. - doi: 10.1046/j.02698463.2001.00558.x

Frolking S, Palace M, Clark DB, Chambers JQ, Shugart HH, Hurtt GC (2009). Forest disturbance and recovery - A general review in the context of space-borne remote sensing of impacts on aboveground biomass and canopy structure. Journal of Geophysical Research 114: GooE02. - doi: 10.1029/2008JG000911

Von Gadow K, Kotze H, Seifert T, Staupendahl K, Álvarez González JG (2015). Potential density and tree survival: an analysis based on South African spacing studies, Southern Forests: a Journal of Forest Science 77:1-8. - doi: 10.2989/ 20702620.2014.984151

Gómez-Aparicio L, Zavala MA, Bonet FJ, Zamora $R$ (2009). Are pine plantations valid tools for restoring Mediterranean forests? An assessment along abiotic and biotic gradients. Ecological Applications 19: 2124-2141. - doi: 10.1890/ 08-1656.1

Gonzalez JGA, Dorado FC, Gonzalez ADR, Sanchez CAL, Gadow K (2004). A two-step mortality model for even-aged stands of Pinus radiata D Don in Galicia (Northwestern Spain). Annals of Forest Science 61: 439-448. - doi: 10.1051/ forest:2004037

Hamilton DA (1986). A logistic model of mortality in thinned and unthinned mixed conifer stands of Northern Idaho. Forest Science 32: 989-1000.

He F, Duncan RP (2000). Density-dependent effects on tree survival in an old-growth Douglas fir. Forest Ecology 88: 676-688.

Hegyi $F$ (1974). A simulation model for managing jack pine stands, In: Proceedings of the IUFRO Meeting S4.01.04 "Growth Models for Tree and Stand Simulation" (Fries J ed). Royal College of Forestry, Stockholm, Sweden, pp. 74-90.

Hosmer DW, Lemeshow S (2000). Applied logistic regression $\left(2^{\text {nd }}\right.$ edn). John Wiley \& Sons, New York, USA, pp. 375.

Hynynen J (1993). Self-thinning models for evenaged stands of Pinus sylvestris, Picea abies and Betula pendula. Scandinavian Journal of Forest Research 8: 326-336. - doi: 10.1080/028275893 09382781

Hynynen J, Niemisto P, Vihera-Aarnio A, Brunner A, Hein S, Velling P (2010). Silviculture of birch (Betula pendula Roth and Betula pubescens Ehrh.) in northern Europe. Forestry 83: 103-119.
- doi: 10.1093/forestry/cppo35

Hynynen J, Repola J, Mielikäinen K (2011). The effects of species mixture on the growth and yield of mid-rotation mixed stands of Scots pine and silver birch. Forest Ecology and Management 262: 1174-1183. - doi: 10.1016/j.foreco. 2011.06.006

Ireland KB, Moore MM, Fulé PZ, Zegler TJ, Keane RE (2014). Slow lifelong growth predisposes Populus tremuloides trees to mortality. Oecologia 175: 847-859. - doi: 10.1007/soo442-014-29515

Janzen DH (1970). Herbivores and the number of tree species in tropical forests. American Naturalist 104: 501-508. - doi: 10.1086/282687

Jose JJS, Farinas MR, Rosales J (1991). Spatial patterns of trees and structuring factors in a trachypogon savanna of the Orinoco Llanos. Biotropica 23: 14-123. - doi: 10.2307/2388296 Jönsson MT, Fraver S, Jonsson BG, Dynesius M, Rydgård M, Esseen PA (2007). Eighteen years of tree mortality and structural change in an experimentally fragmented Norway spruce forest. Forest Ecology and Management 242: 306313. - doi: 10.1016/j.foreco.2007.01.048

Jõgiste K (2010). A basal area increment model for Norway spruce in mixed stands in Estonia. Scandinavian Journal of Forest Research 15: 97 102. - doi: $10.1080 / 02827580050160529$

Kaitaniemi P, Lintunen A (2010). Neighbour identity and competition influence tree growth in Scots pine, Siberian larch, and silver birch. Annals of Forest Science 67: 604. - doi: 10.1051/ forest/2010017

Keddy PA (1989). Effects of competition from shrubs on herbaceous wetland plants: a four year field experiment. Canadian Journal of Botany 67: 708-716. - doi: 10.1139/b89-094

Kenkel NC (1988). Pattern of self-thinning in jack pine: testing the random mortality hypothesis. Ecology 69: 1017-1024. - doi: 10.2307/1941257

Kiviste A, Hordo M, Kangur A, Kardakov A, Korjus $H$, Laarmann D, Lilleleht A, Metslaid S, Sims A (2015). Monitoring and modeling of forest ecosystems: the Estonian Network of Forest Research Plots. Forestry studies (Metsanduslikud uurimused) 62: 26-38.

Kint V, De Wulf R, Lust N (2004). Evaluation of sampling methods for the estimation of structural indices in forest stands. Ecological Modelling 180: 461-476. - doi: 10.1016/j.ecolmodel.20 04.04 .032

Kobe RK (1996). Intraspecific variation in sapling mortality and growth predicts geographic variation in forest composition. Ecological Monograph 66: 181-201. - doi: 10.2307/2963474

Laarmann D, Korjus $H$, Sims A, Stanturf JA, Kiviste A, Köster K (2009). Analysis of forest naturalness and tree mortality patterns in Estonia. Forest Ecology and Management 258: S187S195. - doi: 10.1016/j.foreco.2009.07.014 Lännenpää A, Aakala T, Kauhanen H, Kuuluvainen $T$ (2008). Tree mortality agents in pristine Norway spruce forests in northern Fennoscandia. Silva Fennica 42: 151-163. - doi: 10.142 14/sf.468

Lilleleht A, Sims A, Pommerening A (2014). Spatial forest structure reconstruction as a strategy for mitigating edge-bias in circular monitoring plots. Forest Ecology and Management 316: 47-53. - doi: 10.1016/j.foreco.2013.08.039 
Linares JC, Camarero JJ, Carreira JA (2009). Interacting effects of changes in climate and forest cover on mortality and growth of the southernmost European fir forests. Global Ecology and Biogeography 18: 485-497. - doi: 10.1111/ j.1466-8238.2009.00465.x

Lorimer CG, Dahir SE, Nordheim EV (2001). Tree mortality rates and longevity in mature and oldgrowth hemlock-hardwood forests. Journal of Ecology 89: 960-971. - doi: 10.1111/j.1365-2745.20 01.00619.x

Maleki K, Kiviste A, Korjus H (2015). Analysis of individual tree competition on diameter growth of silver birch in Estonia. Forest Systems 24: 2. [online] URL: http://revistas.inia.es/ index.php/fs/article/view/5742

Vabariigi Valitsuse (2013). Metsa kasvatamise algoritmid [Algorithms for calculation of forest growth]. Vabariigi Valitsuse, Estonia, pp. 4. [in Estonian] [online] URL: http://www.riigiteataja. ee/aktilisa/1030/9201/3006/VV_242m_lisa2.pdf

Moeur M (1997). Spatial models of competition and gap dynamics in old-growth Tsuga heterophylla - Thuja plicata forests. Forest Ecology and Management 94: 175-186. - doi: 10.1016/S03781127(96)03976-X

Monserud RA (1976). Simulation of forest tree mortality. Forest Science 22: 438-444.

Monserud RA, Sterba H (1999). Modelling individual tree mortality for Austrian forest species. Forest Ecology and Management 113: 109123. - doi: 10.1016/S0378-1127(98)00419-8

Monserud RA, Ledermann T, Sterba H (2004). Are self-thinning constraints needed in a treespecific mortality model? Forest Science 50 : 848-858.

Nilson A (1999). Pidev metsakorraldus - mis see on [Continuous forest management - what is it]. Transactions of the Faculty of Forestry, Estonian Agricultural University, Estonia 32: 413. [in Estonian]

Nilson A (2005). Allomeetria võrrandi $\mathrm{N}=\mathrm{aDb}$ ja võrrandi $\mathrm{N}=(\mathrm{a}+\mathrm{bD})-2$ sobivusest puude arvu $\mathrm{N}$ ja nende keskmise diameetri $D$ seose kirjeldamiseks metsa kasvukäigu tabelites [Fitness of allometric equation $\mathrm{N}=\mathrm{aDb}$ and equation $\mathrm{N}$ $=(\mathrm{a}+\mathrm{bD})-2$ for modelling the dependence of the number of trees $\mathrm{N}$ on their mean diameter $\mathrm{D}$ in yield tables]. Forestry studies 43: 159-172.

Nilson A (2006). Modelling dependence between the number of trees and mean tree diameter of stand, stand density and stand sparsity. In: Proceedings of the " 2 nd International Conference on Forest Measurements and Quantitative Methods and Management \& The 2004 Southern Mensurationists Meeting" (Cieszewski CJ, Strub M eds). Hot Springs (AR, USA) 15-18 Jun 2004. Warnell School of Forestry and Natural Resources, University of Georgia, GA, USA, pp. 74-94.

Nyland RD (1994). Careful logging in northern hardwoods. In: "Logging damage: the problems and practical solutions" (Rice JA ed). Forest Research Report 117, Ministry of Natural Resources, Ontario, Canada, pp. 29-51.

Olano JM, Laskurain NA, Escudero A, De La Cruz
$M$ (2009). Why and where do adult trees die in a young secondary temperate forest? The role of neighbourhood. Annals of Forest Science 66: 105. - doi: 10.1051/forest:2008074

Oliver CD, Larson BC (1996). Forest stand dynamics. John Wiley and Sons, New York, USA, pp. 544.

Pederson BS (1998). The role of stress in the mortality of Midwestern oaks as indicated by growth prior to death. Ecology 79: 79-93. - doi: 10.1890/0012-9658(1998)079[0079:TROSIT]2.o. $\mathrm{CO} ; 2$

Perry DA (1985). The competition process in forest stands. In: "Attributes of Trees as Crop Plants. Institute of Terrestrial Ecology" (Cannell MGR, Jackson JE eds). Abbots Ripton, Hunts, UK, pp. 481-506.

Pommerening A (2002). Approaches to quantifying forest structures. Forestry 75: 305-324. - doi: 10.1093/forestry/75.3.305

Powers MD, Palik BJ, Bradford JB, Fraver S, Webster CR (2010). Thinning method and intensity influence long-term mortality trends in a red pine forest. Forest Ecology and Management 260: 1138-1148. - doi: 10.1016/j.foreco.2010.07.0 02

Reineke LH (1933). Perfecting a stand density index for even-aged forests. Journal of Agricultural Research 46: 627-638.

R Development Core Team (2014). R: a language and environment for statistical computing. $R$ Foundation for Statistical Computing, Vienna, Austria. [online] URL: http://www.R-project.org Ripley BD (1981). Spatial statistics. John Wiley and Sons, New York, USA, pp. 255.

Simard SW, Blenner-Hassett T, Cameron IR (2004). Pre-commercial thinning effects on growth, yield and mortality in even-aged paper birch stands in British Columbia. Forest Ecology and Management 190: 163-178. - doi: 10.1016/ j.foreco.2003.09.010

Sims A, Kiviste A, Hordo M, Laarmann D, Gadow K (2009). Estimating tree survival: a study based on the Estonian Forest Research Plots Network. Annales Botanici Fennici 46: 336-352. doi: 10.5735/085.046.0409

Soares P, Tomé M (1999). Distance-dependent competition measures for eucalyptus plantations in Portugal. Annals of Forest Science 56: 307-319. - doi: 10.1051/forest:19990405

Staebler GR (1951). Growth and spacing in an even-aged stand of Douglas-fir. Master's thesis, University of Michigan, Ann Arbor, MI, USA, pp. 46.

Szwagrzyk J, Szewczyk J (2001). Tree mortality and effects of release from competition in an old-growth Fagus-Abies-Picea stand. Journal of Vegetation Science 12: 621-626. - doi: 10.2307/32 36901

Tahvanainen T, Forss E (2008). Individual tree models for the crown biomass distribution of Scots pine, Norway spruce and birch in Finland. Forest Ecology and Management 255: 455-467. doi: 10.1016/j.foreco.2007.09.035

Tarand A, Jaagus J, Kallis A (2013). Eesti kliima minevikus ja tänapäeval [Estonia climate in the past and today]. Tartu University Press, Tartu, Estonia, pp. 632. [in Estonian]

Temesgen H, Mitchell SJ (2005). An individualtree mortality model for complex stands of south-eastern British Columbia. Western Journal of Applied Forestry 20: 101-109.

Thorpe HC, Thomas SC, Caspersen JP (2008). Tree mortality following partial harvests is determined by skidding proximity. Ecological Applications 18: 1652-1663. - doi: 10.1890/07-169 7.1

Uriarte M, Canham CD, Thompson J, Zimmerman JK (2004). A neighbourhood analysis of tree growth and survival in a hurricane-driven tropical forest. Ecological Monographs 74: 591-614. doi: $10.1890 / 03-4031$

Vanclay JK (1994). Modelling forest growth and yield. Applications to mixed tropical forests. CAB International, Wallingford, UK, pp. 312. [online] URL: http://epubs.scu.edu.au/cgi/view content.cgi?article $=1538 \&$ context=esm_pubs Van Mantgem PJ, Stephenson NL (2007). Apparent climatically induced increase of tree mortality rates in a temperate forest. Ecology Letters 10: 909-916. - doi: 10.1111/j.1461-0248.2007.0108 o.x

Wagenmakers EJ, Farrell S (2004). AIC model selection using Akaike weights. Psychonomic Bulletin and Review 11: 192-196. - doi: 10.3758/BF 03206482

Waring RH (1987). Characteristics of trees predisposed to die. Bioscience 37: 569-577. - doi: 10.23 $07 / 1310667$

Wyckoff P, Clark J (2000). Predicting tree mortality from diameter growth: a comparison of maximum likelihood and Bayesian approaches. Canadian Journal of Forest Research 30: 156167. - doi: 10.1139/x99-198

Wykoff WF, Crookston NL, Stage AR (1982). User's guide to the Stand Prognosis Model. Gen. Tech. Rep. INT-133, Intermountain Forest and Range Experiment Station, USDA Forest Service, MN, USA, pp. 112.

Yang Y, Titus SJ, Huang S (2003). Modelling individual tree mortality for white spruce in Alberta. Ecological Modelling 163: 209-222. doi: 10.1016/S0304-3800(03)00008-5

Yao X, Titus SJ, MacDonald SE (2001). A generalized logistic model of individual tree mortality for aspen, white spruce, and lodgepole pine in Alberta mixedwood forests. Canadian Journal of Forest Research 31: 283-291.

Yearbook of Forest (2013). Estonian environment information centre. Tartu, Keskkonnaagentuur/Estonian Environment Agency, Estonia, pp. 244. [In Estonian]

Zeide B (1987). Analysis of the $3 / 2$ power law of self-thinning. Forest Science 33: 517-537.

\section{Supplementary Material}

Tab. S1 - List of variables used to study silver birch mortality.

Link: Maleki_1672@supplo01.pdf 